\title{
Multilingualism in Curriculum Reform (LK20) and Teachers' Perceptions: Mind the Gap?
}

\author{
Gro-Anita Myklevold \\ University of South-Eastern Norway (USN)
}

\author{
Heike Speitz \\ University of South-Eastern Norway (USN)
}

\begin{abstract}
The present study investigates the dichotomous relationship between the official language policies celebrating multilingualism in education on the one hand, and the practice field facing practical challenges concerning their students' multilingualism on the other hand (Cummins \& Persad, 2014; Lundberg, 2019). Document analysis of LK2O and focus groups of teachers were used to investigate two research questions; 1) Which aspects of multilingualism are represented in the core curriculum and in the subject curricula of English, Foreign languages and Norwegian in LK20? and 2) How are aspects of multilingualism in LK20 perceived by teachers of English, Foreign languages and Norwegian?

The findings indicate that there is a gap between the intentions of the ideological curriculum and the perceived and experiential curricula of teachers and students (Goodlad, 1979). When LK20 states that "All pupils shall experience that being proficient in a number of languages is a resource, both in school and society at large", the teachers report that this normative assumption may place too much responsibility on different stakeholders such as students, as some are reluctant to display their multilingual repertoires in class. Furthermore, although the intentions at the ideological level of LK2O seem clear, the operational level remains unclear, since how this claim is to be applied in the classroom is not specified. This, in addition to the fact that multilingualism is conceptualized in a different way in the three language subject curricula of English, Foreign Languages and Norwegian, may explain why teachers report that, despite being positive towards linguistic diversity, they are insecure concerning the operationalization of multilingualism in their classrooms.
\end{abstract}

Keywords: multilingualism, plurilingualism, operationalizations of multilingualism, language policies

\section{Introduction}

Multilingualism, here defined as the "repertoire of varieties of language which many individuals use" (Council of Europe, n.d.) has been promoted by a number of scholars (Conteh \& Meier, 2014; May, 2014; 2019). Within foreign language instruction, it is argued 
that globalization and multilingualism have "changed the conditions under which foreign languages (FLs) are taught, learned, and used" (Kramsch, 2015, p.1), and scholars have promoted the paradigm shift of "the multilingual turn" (Conteh \& Meier, 2014; May, 2014). Multilingualism is also highlighted as an important resource in the Common European Framework of Reference for Languages (CEFR) (Council of Europe, 2001; 2018), and in curriculum reform in Norway (LK06; LK20). The core curriculum in LK20 for example stipulates that "All pupils shall experience that being proficient in a number of languages is a resource, both in school and society at large" (The Ministry of Education and Research, hereafter MER, 2017).

However, multilingualism in curricula may be understood and operationalized in different ways, and despite the educational and political celebratory views of multilingualism (Berthelé, 2021), several studies report that language teachers are insecure in how to comprehend multilingualism and how to implement it in their classrooms (Bredthauer \& Engfer, 2016; Dahl \& Krulatz, 2016; Haukås, 2016; Myklevold, 2021). Other studies show that teachers are reluctant to incorporate languages they themselves do not know in their teaching (Haukås, 2016; Myklevold, forthcoming,; Søndergaard Knudsen et al., 2021). In addition, there is evidence that the students themselves are sometimes reluctant to display and utilize their multilingual repertoires in the classroom (Čeginskas, 2010; Liu \& Evans, 2015; Ticheloven et al., 2019).

Therefore, despite the widespread understanding that multilingualism is "without a doubt an advantage" (Aronin, 2019, p. 1), some researchers have called for more critical approaches within the field (Berthelé, 2021; Jessner \& Kramsch, 2015; Kelly, 2015; McNamara, 2011). It is argued that the discourse seems to be dominated by a "selective celebration of diversity" (Berthelé, 2021, p. 126), and claimed that "multilingual education is a truly challenging enterprise" (Aronin, 2019, p. 1). The present study therefore investigates the seemingly dichotomous relationship between the official language policies and research promoting multilingualism as a resource on the one hand, and the practice field facing practical challenges concerning multilingualism on the other hand (Cummins \& Persad, 2014; Lundberg, 2019). 
The main purpose of this article is to inform our understanding of how aspects of multilingualism are represented in curriculum documents and how teachers perceive and make sense of such aspects. To do so we have conducted a document analysis of LK20 and focus group interviews of teachers of Norwegian, English and German. By teachers' 'perceptions' we here mean opinions and perspectives, and perceptions are often used synonymously with 'attitudes' and 'beliefs' (Pajares, 1992, p. 309).

\section{Background}

Multilingualism has for many years been promoted by the Council of Europe (hereafter $\mathrm{CoE}$ ), an organization which Norway has been a long-term member of and whose language policies it has been clearly influenced by (Simensen, 2010). In the CEFR, for example, multilingualism is highlighted as an important part of a language users' communicative competence (CoE, 2001). Utilizing the term "plurilingualism" rather than "multilingualism", the CEFR states that such plurilingualism involves individuals' ability to draw on all the knowledge and experiences of languages that they know "in order to achieve effective communication with a particular interlocutor" (CoE, 2001, p. 4). The CoE also claims that their plurilingual vision "gives value to cultural and linguistic diversity [...] and emphasizes the need for language learners to "draw on all their linguistic and cultural resources and experiences in order to fully participate in social and educational contexts [...] (CoE, 2020, p. 123).

These are all ideas that have been adopted by Norwegian curricula in the past two decades, first in the 2006 national curriculum (LK06), and more recently in the 2020 curriculum (LK20). Norwegian curricula are regulations that have legal status in education and that teachers need to know in order to plan, implement and evaluate their teaching (Speitz, 2020, p. 40). From a political point of view, curricula legitimize the goals of public education, which include values in society and individual rights (Karseth \& Sivesind, 2009). What remains unclear in these documents, however, is how teachers are to operationalize multilingualism in the classroom and how they can utilize linguistic diversity in a context where their students are assessed in one (target) language and where multilingual teaching practices "still lack concepts and theoretical underpinnings" (Ziegler, 2013, p. 7). 
This lack of - or unclear - operationalization of multilingualism is also grappled with in Sickinghe's work (2013) in her discussions of how Norwegian policy documents, such as yellow papers, educational strategy plans and LK06, conceptualize and operationalize multilingualism differently than the students themselves. She concludes that "to establish more including language education policy discourses, a more precise, multilingually oriented and consistently applied terminology should be used when referring to the different categories of multilingual language users in the Norwegian school system" (Sickinghe, 2013, p. 111).

This view is also supported in other studies, for example in Myklevold (2021) where interviews with teachers and teacher educators revealed that even though they regarded multilingualism as an important resource for both minority and majority language students in language learning, they were insecure about how they could implement multilingualism systematically in their language classrooms. Vikøy \& Haukås (2021) found that teachers of Norwegian seldom encouraged the use of minority students' L1 as a resource in the classroom and that the teachers had a language-as-problem orientation towards the multilingualism of their students.

\section{Conceptual framework}

Multilingualism is a complex phenomenon and there are multiple definitions of the construct. As Berthelé argues, we have to question "the exact meaning of items in our entrenched jargon" and also "think more carefully about the meaning of the words we use." (Berthelé, 2021, p. 8). Therefore, in the following section some terminology and conceptualizations of multilingualism will be discussed before proceeding to the method, findings and discussion sections.

According to Cenoz (2013), multilingualism has both a societal and an individual dimension. In the CEFR, for example, the societal dimension is expressed in the term multilingualism which refers to "the presence in a geographical area, large or small, of more than one variety of language" (CoE, 2007, p. 8). The individual dimension, on the other hand, is manifested in the term plurilingualism, where the focus is on the "the repertoire of varieties of language which many individuals use [...]" (p. 8). As the CEFR is mainly focused on the language learning and language use of the individual learner, the focus there is predominantly on plurilingualism. However, since the individual and the societal dimensions of language 
may be seen to be closely linked (Kramsch, 2014), it may be argued, as Martin-Jones et al. do, that "the difference between multilingualism and plurilingualism is largely theoretical" and that "the terms connote different ways of perceiving the relationship between languages in society and individual repertoire" (Martin-Jones et al., 2012, p. 50). Therefore, the two terms multilingualism and plurilingualism may be seen to differ, but they may also be used interchangeably (Martin-Jones et al., 2012, p. 50). Interestingly, the relationship between language and culture is evident in other parts of the CEFR, for example in the way the CoE links the notion of plurilingualism to the idea of pluriculturalism, where both aspects may be regarded as part of a language user's communicative competence. The CEFR Companion Volume states that: "[the language user] does not keep these languages and cultures in strictly separated mental compartments, but rather builds up a communicative competence to which all knowledge and experience of language contributes and in which languages interrelate and interact" (CoE, Companion volume, 2020, p. 123). The two terms are frequently presented in tandem throughout the document as "plurilingual/pluricultural" (e.g. CoE, Companion Volume, 2020, p. 22), emphasizing the idea that they may be understood as two sides of the same coin. Moreover, and relatedly, plurilingualism is also linked to the notions of intercultural interaction and intercultural competence. A validation, or promotion of language diversity and plurilingual competence is another way of conceptualizing multilingualism, as when it is stated that "The plurilingual vision associated with the CEFR gives value to cultural and linguistic diversity at the level of the individual" (Council of Europe, Companion volume, 2020, p. 123).

We will subsequently return to these conceptualizations of multilingualism from the CEFR in our findings and discussion.

In addition to this, multilingualism may be regarded as an expression of identity, since language "represents and mediates the crucial element of identity" and "constitutes one of the most defining attributes of the individual (Aronin \& Laoire, 2004, p. 11). On a similar note, Cenoz claims that "the choice of one or another language is not only dependent on the availability of the linguistic resources the multilingual individual has at his or her disposal, but at the same time an act of identity" (Cenoz, 2013, p. 9). This also means that even though individuals have skills in several languages, they may still be reluctant to show them, as their repertoires do not always correlate with their preferred language identities. 
Some scholars also link multilingualism to metacognition since studies have shown that metacognition is important in order to strengthen language learning (Haukås et al. 2018; Jessner, 2018; Myklevold, 2021). Like multilingualism, metacognition may have several definitions, but one is “an awareness of and reflections about one's knowledge, experiences, emotions and learning” (Haukås et al., 2018, p. 3), and Jessner is one of the scholars who links multilingualism and knowledge about different languages directly to metalinguistic competences (Jessner, 2018, p. 31).

Since the present study discusses conceptualizations of multilingualism as a resource, the language ideologies theories of Ruiz (1984) and de Jong et al. $(2016 ; 2019)$ may be utilized. Ruiz is preoccupied with language ideologies that underpin national language policies and puts forward three different orientations: language-as-problem, language-as-right and language-as-resource. It is important to note, however, that, as with many other categorizations, these three orientations may overlap and may be regarded as "competing, but not incompatible approaches" (Ruiz, 1984, p. 18).

Firstly, language-as-problem refers to an orientation that comes from previous, reductionistic language views where anything outside of the majority language was identified as problematic or demanding. Secondly, language-as-right is an orientation that considers languages as rudimentary human rights, in order to be free "from discrimination on the basis of language" (Ruiz, 1984, p. 22). However, Ruiz is also critical towards such a rightsperspective in language policies because it may symbolize that "the rights of the few are affirmed over those of the many" (Ruiz, 1984, p. 24). Thirdly, Ruiz proposes a less confrontational language orientation: language-as-resource. This view presupposes that "language is a resource to be managed, developed and conserved" (Ruiz, 1984, p. 28). When languages are viewed as holistic resources within education, industry and diplomacy, language minorities will also be regarded as "important sources of expertise" (Ruiz, 1984, p. 28). Further elaborating on Ruiz' theories, de Jong et al. claim that a fourth orientation is needed, coined "multilingualism-as-a-resource" (de Jong et al., 2019, p. 107). They argue that it is vital to view multilingualism as a resource, and that both teachers and teacher educators have a great responsibility when interpreting and applying new curricula in their classrooms (de Jong et al., 2019, pp. 108-109). 
Since the focus of the present study is on multilingualism in curricula, the curriculum theory of John Goodlad et al.(1979) will be used. Here, they define curriculum theory as "the study of decision-making processes at all the levels [...]: societal, institutional, instructional, and personal" (Goodlad, et al.,1979, p. 51). The theories on curriculum practice and substantive domains will be applied, including the levels of i) the ideological curriculum (the curricula of ideas that emerge from idealistic planning processes), ii) the formal curriculum (the official written syllabus), iii) the perceived curricula (the teachers' perceptions of the syllabus), iv) the operational curricula (how it is operationalized by teachers) and v) the experiential curricula (how it is experienced by students). Even though we will for the most part make use of the ideological, the formal and the perceived levels in our analysis, some of these levels are interrelated and overlap. When our teacher informants talk about how they implement multilingual lesson plans in the classroom, we arguably incorporate the (selfreported) operational level of the teachers in addition. As Goodlad et al. also state "the operational, too, is a perceived curriculum; it exists in the eye of the beholder (Goodlad et al., 1979, p. 62).

To sum up this part, in this article we conceptualize multilingualism in its widest and most holistic sense, both incorporating the societal and the individual dimensions of the concept, and also including aspects of identity and metacognition. We build on a multilingualism as a resource orientation (de Jong et al. 2019) in mainstream classrooms and also integrate dialects and varieties of language in an individual's repertoire, regardless of proficiency level (Haukås, in press; Haukås \& Speitz, 2020). Against this theory and background, two research questions (RQs) have been developed:

$R Q 1$ : Which aspects of multilingualism are represented in the core curriculum and in the subject curricula of English, Foreign languages and Norwegian in LK20?

$R Q 2:$ How are aspects of multilingualism (ML) in LK20 perceived by teachers of English, Foreign languages and Norwegian?

\section{Method}

When doing research on curricula, according to Goodlad, one should always seek to "study actors, actions, and the consequences of actions in natural settings" (Goodlad, 1991, p. 164). Data was therefore collected both through a document analysis of the new national 
curriculum (LK20), and through two focus group interviews with language teachers $(n=6)$. The document analysis contains an analysis of both the core curriculum and the national subject curricula in English, Foreign Languages and Norwegian. As Bowen notes, documents are «stable, "non-reactive" data sources, meaning that they can be read and reviewed multiple times and remain unchanged by the researcher's influence or research process» (Bowen, 2009 , p. 31). Interviews, on the other hand are more prone to be subject to researcher reactivity where the interviewees and their answers are influenced and coloured by what they think the researcher wants to hear (Hammersley, 2008). More generally we believe that a reflexive pragmatist (Alvesson, 2009) view on interviews are relevant, which means recognizing the variety of meanings that may occur, interpreting these in an open and selfcritical way. Epistemologically, we therefore position ourselves through a Deweyan pragmatist orientation where we realize that "language and knowledge do not copy reality, but are means to master a world in transformation" (Kvale \& Brinkmann, 2009, p. 70, our translation).

Document analysis was used to answer $R Q 1$ and interviews were used to answer $R Q 2$. Document analysis was chosen in order to examine how multilingualism was understood, described and operationalized in the core curriculum and in the three language subject curricula of Norwegian, English and Foreign languages at the upper secondary school level. Focus group methodology was chosen since it is beneficial "in exploring and examining what people think, how they think, and why they think the way they do about the issue of importance to them without pressuring them into making decisions or reaching a consensus" (Liamputtong, 2010, p. 5).

\section{Participants}

The informants for the interviews were recruited by means of both purposive and convenience sampling techniques. Participants from within our own network from two upper secondary schools were contacted and via the convenient snowball sampling method also guided us to other potential participants. Participants were then also selected based on their expertise, a purposive aspect, since it was communicated to our contact persons at the two schools that we wanted informants who represented most of the language subjects that were taught in the schools in order to make the most of "the potential of each person to contribute 
to the development of insight and understanding of the phenomenon»"(Merriam \& Tisdell, 2016, p. 127) to employ a cross-linguistic approach and to avoid an "atomistic language view" (Cenoz \& Gorter, 2013). Therefore, teachers who either taught English, German and Norwegian, or a combination of these, were included in both the groups of the sample. Due to the lockdown following the Covid-19 pandemic, it was difficult to find teachers who were willing to participate in the study. The initial plan was to conduct four focus groups interviews, but due to recruitment difficulties we ended up with two mini-focus groups Liamputtong, 2010) with three teachers in each group, and the number of focus group sessions was once for each group. The group interviews lasted from 68 to 85 minutes and were subsequently transcribed verbatim and translated by one of the researchers.

\section{Procedure}

The focus group interviews were conducted physically, not digitally, since "the balance of evidence tends to show that face-to-face focus groups yield data of superior quality compared to online ones" (Bryman, 2016, p. 519). Physical focus groups are also better at establishing rapport and improving interaction between the informants (Bryman, 2016, p. 519), and thus assist in building confidence in the groups as they take turns in expressing their similar or dissimilar interpretations of the construct. The semi-structured interview guide was first piloted on a group of non-sample participants; two teachers of Norwegian and English at the upper secondary school level. The interview guide was found to be a bit too comprehensive, so then it was altered into fewer, more inductive questions (see appended Interview guide). In the interviews, the two focus groups were given prompts in the form of a chart of quotes from the LK20 curriculum, which included quotes from both the core curriculum and the subject curricula. Then they were asked how they interpreted these, how they would work with the multilingual competence aims in their classrooms, and how they perceived the use of other languages than the target languages in their teaching. In addition, they were asked if they had worked with multilingualism prior to the introduction of LK20, to which degree they use mapping of the students' previous languages prior to teaching their students, and to which degree the learning resources or textbooks they use provide them with support concerning multilingual tasks. Probes or follow-up questions were frequently used during the interviews in an attempt to elicit more substantial information, for example when 
the participants mentioned that some students were embarrassed about using their multilingual repertoires in class, one probe was "Could you say something more about this... Do I understand it correctly that they... the students do not want to draw on their multilingual repertoire?"

\section{Data analysis}

In the data analysis process, both analyst and respondent validation techniques were employed (Patton, 1999, pp. 1195-96). Excerpts of the focus group interviews and LK20 were cross-coded with two other independent researchers in order to compare them to the authors' findings to reduce potential researcher bias, and some of the codes were adjusted accordingly. The data findings were also subjected to member-checking, or respondent validation, where one participant from each of the focus groups was asked to reevaluate the findings and see if the findings resonated with their opinions (Patton, 1999, pp. 1195-96). The informants only elaborated further on their initial responses and had no major alterations they wanted to incorporate.

Although it may be argued that "[t]ranscribing the interviews is in fact an initial data analysis" (Liamputtong, 2011, p. 165), the concrete coding began after the second interview. Both the document analysis and the interview transcripts were coded utilizing an open coding strategy and the codes were derived at abductively, that is categories emerge iteratively, through a constant comparison (Onwuegbuzie \& Leech, 2007). More specifically, the coding of the curriculum documents started out deductively with a search for formulations which corresponded to the definitions of multilingualism discussed in the Conceptual framework section, for example multilingualism as linguistic and cultural diversity (see above). Coded segments from the document analysis and the focus groups were compared by examining what kinds of topics were present in both data sets, if there were any broad patterns across sets and how these either correlated or differed (Bowen, 2008). Identity is an example of a category that was derived from both sets, and that differed in its representation; as having a positive and safe connotation in the document analysis, and as containing a multifaceted and partly unfavourable connotation in the focus group interviews. 


\section{Findings}

\section{Document Analysis}

The document analysis was conducted in order to answer $R Q 1$ : Which aspects of multilingualism are represented in the core curriculum and in the subject curricula of English, Foreign languages and Norwegian in LK20? This part of the study therefore belongs to the levels of the ideological and formal curricula (Goodlad et al., 1979). Data will be presented in the following order: first the Core curriculum, and then the subject curricula for Norwegian, English and Foreign languages. The focus of this article is on mainstream, multilingual language classes, and therefore Norwegian as a second language is not included in our analysis this time.

In the Core curriculum section 1.2 Identity and cultural diversity (MER, 2017), there are three occurrences of elements relating to multilingualism. The first occurrence refers to language use, communication, belonging, and cultural awareness:

Opplæringen skal sikre at elevene blir trygge språkbrukere, at de utvikler sin språklige identitet, og at de kan bruke språk for å tenke, skape mening, kommunisere og knytte bånd til andre. Språk gir oss tilhørighet og kulturell bevissthet.

[The teaching and training shall ensure that the pupils are confident in their language proficiency, that they develop their language identity and that they are able to use language to think, create meaning, communicate and connect with others. Language gives us a sense of belonging and cultural awareness]

The Norwegian original, authoritative text was chosen for this quote because the noun 'språk' may be interpreted as either indefinite singular ('language') or plural ('languages'). Interestingly, the singular noun 'language' is used in the official English translation.

The second occurrence relating to multilingualism in the Core Curriculum is about linguistic diversity in society. It states, "knowledge about the linguistic diversity in society provides all pupils with valuable insight into different forms of expression, ideas and traditions" (MER, 2017).

The third occurrence relating to multilingualism is that "all pupils shall experience that being proficient in a number of languages is a resource, both in school and society at large" (MER 2017). These passages from the Core Curriculum are clearly of ideological and 
normative character (Goodlad, 1979). It remains unclear, how this claim is to be understood and applied. What does it for example mean to be proficient in a number of languages?

Turning to the three subject curricula in English, Foreign languages and Norwegian, they contain variations of the same sentence, for example: "Through working with the Norwegian subject, the pupils shall become confident language users who are aware of their own linguistic and cultural identity in an inclusive community in which multilingualism is valued as a resource." (MER, 2019a, italics added). While the curriculum for Norwegian puts emphasis on multilingualism as a resource in communities, the curricula for English and Foreign languages seem to highlight individual multilingualism: "The pupils shall experience that the ability to speak several languages is an asset at school and in society in general." (MER, 2019b) and "The subject shall help the pupils to gain understanding of linguistic and cultural diversity. Through the subject, the pupils shall be allowed to experience that multilingualism is an asset, both in school and in society at large" (MER 2019c).

As for use of terminology, the terms multilingualism or multilingual, 'flerspråklighet' or 'flerspråklig' - noun or adjective - occur in all three language curricula, as well as the ability to speak several languages'. All three language curricula also include elements about comparing languages or transferring linguistic knowledge from other languages the students know, although the strongest focus on this may be viewed in the English subject curriculum, where one of the competence aims states that the students should be able to compare English to "other languages with which the pupil is familiar" (MER, 2019b). This is a phrase which is used at all levels in the English subject curriculum.

Linguistic diversity, often related to the Sami and Scandinavian languages, is another central term in the curriculum for Norwegian, and one of six core elements in the subject. In English, linguistic diversity is related to an international context, intercultural communication and the English-speaking world: "Working with texts in English helps to develop the pupils' knowledge and experience of linguistic and cultural diversity" and "explore and describe ways of living, ways of thinking, communication patterns and diversity in the Englishspeaking world" (MER, 2019b). In the Foreign language curriculum, there is a more individual perspective, connecting linguistic diversity to students' intercultural competence: "Intercultural competence means developing curiosity about, insight into and understanding 
of cultural and linguistic diversity, both locally and globally, to interact with others." (MER, 2019c).

Linguistic and cultural identity is also highlighted in the Norwegian subject curriculum: "Through working with the Norwegian subject, the pupils shall become confident language users who are aware of their own linguistic and cultural identity in an inclusive community in which multilingualism is valued as a resource" (MER, 2019a). The English subject elaborates on this perspective and relates multilingualism to intercultural competence: "[The pupils] shall build the foundation for seeing their own identity and others' identities in a multilingual and multicultural context" (MER, 2019b). In the curriculum for Foreign languages, multilingualism is emphasized mostly as an aspect of language learning. It constitutes one of the four core elements of the subject, called Language Learning and Multilingualism: "In the encounter with the foreign-languages subject, the pupils are already multilingual and have extensive language-learning experiences from various contexts" (MER, 2019c).

To sum up, we can say that all three curricula, Norwegian, English, and Foreign languages, contain aspects of multilingualism as a resource. At the same time, there are differences regarding how the idea of "resources" is represented. The Norwegian subject description has a clear emphasis on the students becoming confident language users, and on linguistic and cultural identity. It focuses on the two variants of written Norwegian: Bokmål, Nynorsk, as well as Sami and other languages, including neighboring, or Scandinavian languages. In addition, there is also a clear focus on local and national contexts (expanding contexts from lower to higher grades).

As for the English curriculum, its main multilingual perspective is the comparison with other languages the students have encountered. We interpret this to include both languages of schooling and students' home languages. English is clearly presented as the international language of communication and a key to experiencing both multilingual and multicultural diversity.

In the Foreign languages curriculum, which involves the last languages introduced in school (usually in $8^{\text {th }}$ grade), language learning is even more explicitly to be based on the students' previously learnt languages, within and outside of school. The students are seen as being "already multilingual" and having "extensive language-learning experiences from 
various contexts" (MER, 2019c). This curriculum is the one that most explicitly connects metacognition to language learning, although the English subject curriculum also encourages a comparative approach for language learners.

\section{Focus group interviews}

The focus group interviews were conducted in order to answer RQ2: How are aspects of multilingualism in LK20 perceived by teachers of English, Foreign languages and Norwegian? This part of the study belongs to Goodlad's perceived level of the curriculum and to the instructional domain where teachers adapt the curriculum into practice (Goodlad, 1979).

First, in response to the question of how they perceive "multilingualism as a resource" in the Core curriculum, the teachers reported that they viewed it as a tool for communication. Interestingly, they also related it to the idea of pluriculturalism as an aspect of communicative competence (Council of Europe, 2018). For example, they stated that "not only is [multilingualism] a means of communication, but also...a way of approaching other cultures." The teachers also viewed the concept as "a lovely way of displaying diversity", which may also be linked to a validation of linguistic and cultural diversity in classroom settings.

Second, the teachers saw multilingualism as a way of improving both the cognitive and the metacognitive aspects of language learning. One informant said that multilingualism may be used "not only as a tool for communication, but also as a development on a cognitive level", and another teacher reported that it was "a way of thinking differently, on a metalevel, regarding languages". Another informant argued that "the more you draw on languages, the broader understanding of languages you get, also of your own language [...]”.

A third finding relates to the teachers' insecurity regarding the operationalization of multilingualism as a resource in the core curriculum and the multilingual competence aims in the subject curricula. One of the teachers asked critical questions about the realism in - and the operationalization of - how the students will obtain these experiences that multilingualism is a resource regardless of contexts:

T2: Concerning 'language as a resource', that is also about getting the experience that we view it as such. Because what is not described here [in the core curriculum] is who... where... how do you get this experience? Because then...in a way...your peers, the teachers, all the people you encounter, 
society must... uh... attribute.... positive value to it. And that is not...given. That it is like that, even though it is so nicely put in this...core curriculum.

Some informants also claimed that they had not received support and lacked competence in employing multilingual lesson plans:

T5: I think it is fun, especially because there are so many languages popping up that one did not know the students knew. But then... it is difficult to know exactly how to work with it! [...] We have not attended any courses in this.

The teachers also reported that they had not received new textbooks from the school, that they sometimes used LK06 textbooks even after the introduction of LK20, and that even the new textbooks had only a "little bit more focus [on multilingualism] than it has previously been", but "not to a large degree".

A fourth and last finding indicates that the teachers also linked multilingualism to an expression of identity for the students, and that such a multilingual identity could both have positive and negative connotations for them. During a language comparison task in the Norwegian classes where the students were asked to choose one language they knew or were currently learning, and then compare its syntax, lexis and morphology with Norwegian, some students displayed a sense of pride in their multilingual identity, whereas other students were reluctant to show their multilingual identity. One teacher reported that "I had two Somali boys and they both presented their home language Somali. It was really elaborately done and they were very eager to do it, so that was good". However, other teachers reported having several experiences with students who either showed great reluctance towards, or even refused to display their full multilingual repertoires. One teacher argued that some of the students who had a non-Norwegian mother tongue "had a big opportunity to benefit from that", but then “experienced that there were two boys who didn't want to use their own mother tongue to compare [Norwegian] with! They would rather choose English". The teachers perceived that this was due to several factors linked to their identity and that the students did not want to stand out from the collective:

T4: $[\ldots]$ there are some students who are embarrassed to speak another language. $[\ldots]$

I: Is it, can you elaborate on this... do I understand it correctly that some students do not want to draw on their multilingual repertoires?

T4: Yes

T5: Yes 
T6: Yes. They do not want to acknowledge it.

T4: They want to fit in, you see.

The teachers also argued that "[...] there is too much focus on the student, so they may think it is uncomfortable", that "it may be due to personality", and that "not everyone likes that [attention]". One of the teachers also firmly claimed that "I think that some students oppose [multilingualism]" and provided a specific example of a girl in class who did not want to display her full multilingual repertoire:

T1: I have a girl in my English class, who lived some years in Iceland, and then we had a listening exercise that thematized Icelandic wordsmiths who made Icelandic words instead of using originally English words. And everybody knew that she had been living on Iceland, and she knows Icelandic, but she did not want that to be focused on. It was embarrassing for her, that it was referred to, so even if it was an excellent opportunity for her to experience that knowing several languages is a resource, for example in that listening exercise, she was not interested in doing that! Because she did not want to stand out from the others $[\ldots]$.

\section{Discussion}

When comparing the results from the document analysis and the teachers' focus group interviews, which included quotes from LK20, the findings indicate that there is a gap between the intentions of the ideological curriculum and the perceived and experiential curricula of teachers and students (Goodlad et al., 1979). When national curricula, like the Norwegian LK20 state that "All pupils shall experience that being proficient in a number of languages is a resource, both in school and society at large" (MER, 2017, italics added), there is an ideological and a normative assumption that may expect too much and place too much responsibility on different stakeholders such as students and teachers. The intentions of LK20 seem clear, but the operational level remains unclear, since several teachers express uncertainty regarding how to implement multilingual practices in the classroom, especially since some of their students did not always view their own multilingualism as a resource.

On the formal level of curricula (Goodlad et al., 1979), all the three language subject curricula and the Core curriculum seem to contain a multilingualism as resource orientation (de Jong et al., 2019). At the same time, they highlight different aspects of multilingualism. The curriculum in Foreign languages emphasizes students' previous language learning experiences, while the curriculum in English focuses on language comparison, and the one in Norwegian underscores linguistic and cultural identity. These rather different foci may be 
connected to the order and place which the different languages are allocated in the educational system, but they may also add to an inconsistent use of terminology connected to multilingualism. Many aspects of multilingualism in LK20 are left untreated, for example the questions of what it means to be proficient in a number of languages, whether dialects and regional varieties are included in 'languages', how competence aims such as 'experiences from earlier language learning $[\ldots] "$ can be assessed and how a regulation can be valid for both "school and society at large."

On the perceived level of curricula (Goodlad et al., 1979), a lack of consistency in the use of terminology may also add to the insecurity that the teachers reported, since LK20 contains little guidance on how to understand and operationalize multilingual pedagogy in a coherent and systematic way. Multilingualism and globalization may have "destabilized the codes, norms, and conventions" for foreign language teachers, which implies a need for a new pedagogy (Kramsch, 2015, p.1). This requires courses and continuing education for the teachers. The teachers reported that they were positive towards linguistic diversity, but that it was "difficult to know exactly how to work with it", since they lacked competence in how to operationalize multilingualism. This is also supported in other studies (Bredthauer \& Engfer, 2016; Dahl \& Krulatz, 2016; Haukås, 2016). The teachers in the focus groups reported that they had received no courses or guidance in how to understand and implement a multilingual pedagogy, and the textbooks did not contain a focus on multilingual tasks either. This lack of support for the teachers may be seen as one of the biggest obstacles when attempting to implement 'the multilingual turn' in language classrooms (Meier, 2017), and of course may contribute to the fact that the teachers are insecure as to when, how and to what degree they can work with competence aims related to multilingualism in LK20.

On the experiential level of curricula (Goodlad et al., 1979), as reported through the teachers, not all of their students are eager to utilize or display their multilingual repertoire in class, which is a finding supported by other studies (Čeginskas, 2010; Liu \& Evans, 2015; Ticheloven et al. 2019). This may have several reasons, but it nevertheless made the teachers insecure as to what degree they could utilize their students' multilingual repertoires in language classes. The teachers related their students' reluctance to the important identityaspect in language learning; that language is "a central medium through which we think, define ourselves and present ourselves to others" (Rutgers et al., 2021). This may be one of 
the reasons why teachers hesitate in making use of multilingual elements as they are insecure of how to utilize their students' full multilingual repertoires without distressing the students, or forcing certain identities on them that the students themselves do not want to present to peers or be defined by.

Therefore, it is important to listen to these crucial educational stakeholders and their practical challenges concerning multilingualism in language classrooms, both in order to avoid a one-sided, "celebratory" focus of multilingualism (Berthelé, 2021), often portrayed in language policy documents such as LK20, and to try to fill the gap between the ideological and formal level on the one side, and the operational, perceived and experiential level of curricula (Goodlad et al.,1979) on the other. To tackle the more practical and challenging aspects of multilingualism is also important in order to avoid tokenism (Ticheloven et al., 2019). As one of our informants said in the member checking procedure: "It is about taking multilingualism seriously, not just as a token of differentness".

The findings also indicate that there has been little support for the teachers in implementing a multilingual pedagogy, which is unfortunate when introducing a new curriculum reform (LK20) containing important values and competence aims relating to multilingualism. The teachers in our focus groups seemed to have received no courses in multilingual approaches in language teaching, which was seen as challenging, a finding also confirmed in other studies (Bredthauer \& Engfer, 2016). The teachers reported that the learning resources they used contained few multilingual tasks, even the textbooks developed for LK20 lacked a systematic multilingual focus. Many teachers look to their textbooks when they plan their teaching, and therefore this may prevent the teachers from implementing multilingual practices. As Meier also argues, one of the main challenges hindering the implementation of the multilingual turn, in addition to the monolingual bias, is "a lack of guidance for teachers" (Meier, 2016, p. 1). Therefore, to provide more support and professional development for the teachers through courses, continuing education and properly developed multilingual textbooks seems to be an important implication of this study.

\section{Limitations}

In our analysis of the documents in LK20 and the focus group interviews, there are several limitations. Both the document analysis and the focus group interviews consisted of small samples, and the inclusion of more documents and more informants may have yielded 
other and more comprehensive results. As for the document analysis, the sample consisted of only four LK20 documents, and may provide incomplete detail to sufficiently answer our research questions since most documents are made for purposes other than research (Bowen, 2009, p. 31). As for the focus groups, the sample was a small and rather homogenous sample of teachers, which in itself is a limitation. Furthermore, the self-reported behavior by the teachers does not always get an accurate picture of their practices or classrooms, so in future research on multilingual classrooms, a triangulation of observations, interviews and questionnaires would perhaps be beneficial to achieve a more comprehensive look at how the teachers operationalize multilingualism in their language classrooms.

\section{Conclusion}

More research is therefore needed on how to operationalize multilingualism in language classrooms, both involving student and teacher perspectives. The students' different and evolving multilingual identities, their experiences with, and sometimes reluctance towards multilingualism are important factors to consider, both when teaching and doing research on multilingualism (Aronin, 2019; Cenoz, 2013). To focus more specifically on the students' perspectives and experiences with multilingualism in the classroom could therefore benefit future research in the field. In addition, a further investigation of the relationship between official language policies on the one hand, and actual classroom practices on the other hand also seems to be necessary (Cummins \& Persad, 2014; Lundberg, 2019). When introducing new curricula that contains several aspects of multilingualism, the teachers are crucial stakeholders, and should therefore be involved in more empirical studies on how multilingualism can be conceptualized and operationalized in contemporary language classrooms. The field of multilingualism may be seen to "still lack concepts and theoretical underpinnings" (Ziegler, 2013, p. 7), and such empirical studies may contribute to more practice-grounded conceptualizations of multilingualism.

However, there is also a need to be critical in the complex field of multilingualism, and to not let the discourse be dominated by a "selective celebration of diversity" (Berthelé, 2021, p. 126). When working with, and doing research on multilingualism, it is necessary to pay attention to both the opportunities and the challenges that may emerge (Jessner \& 
Kramsch, 2015; Myklevold, forthcoming). This is essential, both in order to achieve a “fruitful future scholarly engagement with linguistic diversity [...]" (Berthelé, 2021, p.126), and to further improve our understanding of the construct and the field (Aronin, 2019; Berthelé, 2021).

\section{References}

Alvesson, M. (2003). Beyond neopositivists, romantics, and localists: A reflexive approach to interviews in organizational research. Academy of Management Review, 28(1), 13-33. doi: https://doi.org/10.5465/amr.2003.8925191

Aronin, L. (2019). Challenges in multilingual education: Streamlining affordances through Dominant Language Constellations. Stellenbosch Papers in Linguistics Plus, 58, 235-256.

Aronin, L., \& Laoire, M. O. (2004). Exploring multilingualism in cultural contexts: Towards a notion of multilinguality. In C. Hoffman \& J. Ytsma (Eds.), Trilingualism in family, school and community (pp. 11-29). Clevedon: Multilingual Matters

Berthelé, R. (2021) The selective celebration of linguistic diversity: Evidence from the Swiss language policy discourse. In Journal of Multilingual and Multicultural Development, 42(2), 125-136. doi: https://doi.org/10.1080/01434632.2020.1715989

Bowen, G. (2009). Document Analysis as a Qualitative Research Method. Qualitative Research Journal, 9(2), 27-40. doi: https://doi.org/10.3316/QRJ0902027

Bredthauer, S. \& Engfer, H. (2016). Multilingualism is great - but is it really my business? Teachers' approaches to multilingual didactics in Austria and Germany. Sustainable Multilingualism, 9, 105-121. doi: http://dx.doi.org/10.7220/2335-2027.9.5

Bryman, A. (2012). Social Research Methods. Oxford: Oxford University Press.

Ceginskas, V. (2010). Being 'the strange one or 'like everybody else': School education and the negotiation of multilingual identity. International Journal of Multilingualism, 7(3), 211224. doi: https://www.tandfonline.com/doi/full/10.1080/14790711003660476

Cenoz, J. (2013). Defining Multilingualism. Annual Review of Applied Linguistics, 33, 3-18. doi:10.1017/S026719051300007X

Cenoz, J. \& Gorter, D. (2011). A Holistic Approach to Multilingual Education: Introduction. Modern Language Journal 95(3), 339-343. doi: https://doi.org/10.1111/j.1540-

4781.2011.01204.x 
Conteh, J. \& Meier, G. (2014). The Multilingual Turn in Languages Education: Opportunities and Challenges. Bristol: Multilingual Matters.

Council of Europe (2001). Common European Framework of Reference for Languages: Learning, teaching, assessment. Strasbourg: Council of Europe Publishing. https://rm.coe.int/16802fc1bf

Council of Europe (2008). From Linguistic Diversity to Plurilingual Education: Guide for the Development of Language Education Policies in Europe. Strasbourg: Council of Europe Publishing. https://rm.coe.int/16806a892c

Council of Europe (2018). Common European Framework of Reference for Languages: Learning, teaching, assessment. Companion Volume. Strasbourg: Council of Europe Publishing. www.coe.int/lang-cefr

Cummins, J. and Persad, R. (2014) Teaching through a multilingual lens: The evolution of EAL policy and practice in Canada. Education Matters: The Journal of Teaching and Learning, 2(1), 1-40.

Dahl, A. and Krulatz, A. (2016) Engelsk som tredjespråk: Har lærere kompetanse til å støtte flerspråklighet? Acta Didactica Norge, 10(1), 1-18.doi: https://doi.org/10.5617/adno.2397

de Jong, E. J., Li, Z., Zafar, A. M. \& Wu, C.-H. (2016). 'Language policy in multilingual contexts: Revisiting Ruiz's "language-as-resource” orientation'. Bilingual Research Journal, 39(3-4), 200-212. doi: 10.1080/15235882.2016.1224988

de Jong, E. J., Yilmaz, T., \& Marichal, N. (2019). A multilingualism-as-a-resource orientation in dual language education. Theory into Practice, 58(2), 107-120.

Forbes, K., Evans, M., Fisher, L., Gayton, A., Liu, Y. \& Rutgers, D. (2021). Developing a multilingual identity in the languages classroom: the influence of an identity-based pedagogical intervention. The Language Learning Journal, 49(4), 433-451. https://www.tandfonline.com/doi/full/10.1080/09571736.2021.1906733

Goodlad, J. I., Klein, F., \& Tye, K. A. (1979). The domains of curriculum and their study. In J. I. Goodlad (Ed.), Curriculum inquiry: The study of curriculum practice, 43-76. New York: McGraw-Hill.

Goodlad, J.I (1991). The Wonderful World of Curriculum Inquiry. Journal of Curriculum and Supervision, Vol.6(2), 161-166.

Hammersley, M. (2008). Questioning qualitative inquiry: Critical essays. Thousand Oaks: Sage.

Haukås, Å. (2016) Teacher's beliefs about multilingualism and a multilingual pedagogical approach. International Journal of Multilingualism, 13(1), 1-8. http://www.tandfonline.com/doi/pdf/10.1080/14790718.2015.1041960?needAccess=true 
Haukås, Å. (in press). Who are the multilinguals? Students' definitions, self-perceptions and the public debate. In W. Bennett, \& L. Fisher (Eds.), Multilingualism and identity:

Interdisciplinary perspectives. Cambridge University Press

Haukås, Å., Bjørke, C., \& Dypedahl, M. (2018). Introduction. In Haukås, Å., Bjørke, C., \& Dypedahl, M. (Eds), Metacognition in Language Learning and Teaching, 1-10. New York: Routledge.

Haukås, Å. \& Speitz, H. (2020). Plurilingual learning and teaching. In Carlsen, C., Dypedahl, M. \& Hoem Iversen, S. (Eds.) Teaching and Learning English (2nd edition), 61-80. Oslo: Cappelen Damm Akademisk.

Iversen, J. (2017) The role of minority students' L1 when learning English. Nordic Journal of Modern Language Methodology, 5(1), 35-47.

Jessner, U. \& Kramsch, C. (2015). The Multilingual Challenge: Cross-Disciplinary Perspectives. Berlin/Boston: De Gruyter Mouton.

Jessner, U. (2018). Metacognition in Multilingual Learning: A DMM Perspective. In Haukås, A., Bjørke C. \& Dypedahl, M. (Eds.) Metacognition in Language Teaching and Learning, 3147. New York: Routledge.

Karseth, B. \& Sivesind, K. (2009) Læreplanstudier - perspektiver og posisjoner. In Dale, E.L. (ed.) Laereplan $i$ et forskningsperspektiv, 23-61. Oslo: Universitetsforlaget.

Kelly, M. (2015). Challenges to multilingual language teaching: Towards a transnational approach. European Journal of Language Policy 7(1), 65-

83. https://www.muse.jhu.edu/article/585547.

Kramsch, C., 2014. Teaching foreign languages in an era of globalization: Introduction. The modern language journal, 98(1), 296-311.

https://onlinelibrary.wiley.com/doi/epdf/10.1111/j.1540-4781.2014.12057.x

Krulatz, A. and Iversen, J. (2020). Building inclusive language classroom spaces through multilingual writing practices for newly-arrived students in Norway. Scandinavian Journal of Educational Research 64(3), 372-388.

Kunnskapsdepartementet (2017). Overordnet del-verdier og prinsipper for grunnopplaeringen. Fastsatt som forskrift ved kongelig resolusjon. Læreplanverket for Kunnskapsløftet 2020. https://www.udir.no/lk20/overordnet-del/?lang=nob.

Kvale, S. and Brinkmann, S. (2009). Det kvalitative forskningsintervju. (2nd edition). Oslo: Gyldendal Akademisk Forlag.

Liamputtong, P. (2010). Qualitative Research Methods. ( $3^{\text {rd }}$ edition). Oxford: Oxford University Press. 
Liu, Y. and Evans, M. (2015): Multilingualism as legitimate shared repertoires in school communities of practice: Students' and teachers' discursive constructions of languages in two schools in England, Cambridge Journal of Education, 46(4), 553-568.

doi:10.1080/0305764X.2015.1091441

Lundberg, A. (2019) Teachers' beliefs about multilingualism: Findings from Q method research. Current Issues in Language Planning, 20(3), 266-283.

Martin-Jones, M., Blackledge, A. \& Creese, A. (Eds.) (2012). The Routledge handbook of multilingualism. London, UK: Routledge.

May, S. (2014) Disciplinary divides, knowledge construction, and the multilingual turn. In S. May (Ed.), The Multilingual Turn: Implications for SLA, TESOL, and Bilingual Education, 731. New York, NY: Routledge.

May, S. (2019). Negotiating the multilingual turn in SLA. The Modern Language Journal, 103 (Supplement 2019), 122-129. DOI: 10.1111/modl.125310026-7902/19/122-12

McNamara, T. (2011). Multilingualism in Education: A Poststructuralist Critique. The Modern Language Journal, 95(3), 430-441. http://www.jstor.org/stable/41262377

Meier, G.S. (2016). The multilingual turn as a critical movement in education: Assumptions, challenges and a need for reflection. Applied Linguistics Review, 8(1), 131-161

Merriam, S. B., \& Tisdell, E. J. (2016). Qualitative research: A guide to design and implementation (4th ed.). San Francisco, CA: Jossey-Bass Publishers.

Ministry of Education and Research (2017). Core Curriculum - values and principles for primary and secondary education. Established as a regulation by royal decree (translation of the official Norwegian curriculum text)

Ministry of Education and Research (2019a) Curriculum for Norwegian (NORO1-06) Established as regulation (translation of the official Norwegian subject curriculum text). https://www.udir.no/lk20/nor01-06?lang=nob

Ministry of Education and Research (2019b) Curriculum in English (NORO1-06) Established as a Regulation (translation from Norwegian Bokmål of the official Norwegian subject curriculum text). https://www.udir.no/lk20/eng01-04

Ministry of Education and Research (2019c) Curriculum for Foreign Languages (FSP01-02). Established as a regulation (translation from Norwegian Bokmål of the official Norwegian subject curriculum text). https://www.udir.no/lk20/fsp01-02

Myklevold, G.-A. (2021). "That is a big shift for us": Teachers' and teacher educators' perceptions of multilingualism and multilingual operationalizations. In Globe: A Journal of Language, Culture and Communication, 12, 67-82. doi: 10.5278/ojs.globe.v12i.6499.

Myklevold, Gro-A. (in press). Operationalizing multilingualism in a foreign language classroom in Norway: opportunities and challenges. In Krulatz, A., Neokleous, G. \& Dahl, A. 
(Eds.), Theoretical and Applied Perspectives on Teaching Foreign Languages in Multilingual Settings: Pedagogical Implications. Multilingual Matters.

Onwuegbuzie, A. J., \& Leech, N. L. (2007). Validity and qualitative research: An oxymoron? Quality \& Quantity. International Journal of Methodology, 41, 233-249. doi:10.1007/s11135$006-9000-3$

Pajares, Frank M. (1992). 'Teachers' beliefs and educational research: Cleaning up a messy construct'. Review of Educational Research, 62(3), 307-332

Patton, M. Q. (1999). Enhancing the Quality and Credibility of Qualitative Analysis. HSR: Health Services Research, 34(5), 1189-1208.

Ruiz, Richard (1984). 'Orientations in language planning'. NABE Journal, 8(2), 15-34.

Rutgers, D., Evans, M., Fisher, L., Forbes, K., Gayton, A., \& Liu, Y. (2021). Multilingualism, multilingual identity and academic attainment: Evidence from secondary schools in England. Journal of Language, Identity \& Education, 1-18. doi:10.1080/15348458.2021.1986397

Sickinghe, A.-V. (2013). The Discursive Construction of Multilinguals in Norwegian Language Education Policy. NordAnd - Nordisk Tidsskrift for Andrespråksforskning, 8(2), 87-114.

Simensen, A. M. (2010). Fluency: an aim in teaching and a criterion in assessment. Acta Didactica Norge, 4(1). https://doi.org/10.5617/adno.1048

Speitz, H. (2020) National Curricula and International Perspectives. In Carlsen, C., Dypedahl, M. \& Hoem Iversen, S. (Eds.) Teaching and Learning English (2 ${ }^{\text {nd }}$ edition), 40-52. Oslo:

Cappelen Damm Akademisk.

Søndergaard Knudsen, H.B., Donau, P.S., Mifsud, C.L., Papadopoulos, T.C., \& Dockrell, J.E. (2021). Multilingual Classrooms: Danish Teachers' Practices, Beliefs and Attitudes.

Scandinavian Journal of Educational Research, 65(5), 767-782.

https://www.tandfonline.com/doi/full/10.1080/00313831.2020.1754903

Ticheloven, A., Blom, E., Leseman, P. \& McMonagle, S. (2019). Translanguaging challenges in multilingual classrooms: Scholar, teacher and student perspectives. International Journal of Multilingualism 18(3), 1-24.

Vikøy, A. \& Haukås, Å. (2021). Norwegian L1 teachers' beliefs about a multilingual approach in increasingly diverse classrooms, International Journal of Multilingualism. Ahead of print, 1-20. doi: https://doi.org/10.1080/14790718.2021.1961779

Ziegler, G. (2013). Multilingualism and the language education landscape: Challenges for teacher training in Europe. Multilingual Education, 3(1), 1-23.doi:

https://doi.org/10.1186/2191-5059-3-1 
Focusgroups, semi-structured interviewguide (Myklevold \& Speitz, 2022):

\section{A) Generelt om overordnet del og kompetansemål i Fagfornyelsen}

i) I Overordnet del av Læreplanen står det: Alle elever skal få erfare at det $\stackrel{a}{a}$ kunne flere språk er en ressurs $i$ skolen og $i$ samfunnet. -Hvordan tolker dere det?

ii) Og hvis vi ser på de konkrete læreplanene står det bl.a. «Elevene skal kunne «sammenligne sartrekk ved norsk med andre språk og vise hvordan språklige møter kan skape språkendringer» (norsk) og «Explore and describe some linguistic similarities and differences between English and other languages he or she is familiar with and use this in his or her language learning" (engelsk).

-Hvordan tolker dere de nye kompetansemålene rundt flerspråklighet $\mathrm{i}$

Fagfornyelsen?

iii) -Hvordan tolker dere begrepet «andre språk» i norskfaget/«other languages» i engelskfaget?

\section{B) Prosesser rundt språklæring, innføring av LK20 og læremidler}

i) -I hvilken grad finner dere ut av/kartlegger andre språk elevene kan?

ii) -Hvordan har dere jobbet i forkant med innføringen av de nye læreplanene?

iii) -I hvilken grad tematiserer lærebøkene/læringsressursene dere bruker i Fagfornyelsen flerspråklighet?

\section{C) Kjerneelementer i norsk, engelsk, fremmedspråk}

i) -Hvordan kan man forstå og jobbe med disse kjerneelementene?:

-Språklæring og flerspråklighet, FREMMEDSPRA $K$ :

I møte med faget fremmedspråk er elevene allerede flerspråklige og har

omfattende språklaringserfaring fra ulike kontekster. 


\section{- Language learning, ENGELSK:}

Language learning refers to identifying connections between English and other languages the pupils know, and to understanding how English is structured.

\section{-Tekst i kontekst, NORSK:}

De skal utforske og reflektere over skjønnlitteratur og sakprosa på bokmål og nynorsk, på svensk og dansk, og i oversatte tekster fra samiske og andre språk.

\section{D) Kompetansemål i norsk, engelsk og fremmedspråk}

i) -Hvordan kan man forstå og jobbe med disse kompetansemålene?:

- Etter Vg1, Nivå 1, FREMMEDSPRÅK: bruke relevante laerings- og kommunikasjonsstrategier, digitale ressurser og erfaringer fra tidligere språklaering $i$ laeringsprosessen

- Etter Vg1: ENGELSK: use knowledge of similarities between English and other languages with which the pupil is familiar in language learning

-Etter Vg1, NORSK: lese, analysere og tolke nyere skjønnlitteratur på bokmål og nynorsk og $i$ oversettelse fra samiske og andre språk

\section{E) Avsluttende spørsmål}

i) -Har dere andre kommentarer rundt innføringen av LK20 og flerspråklighet i LK20 som jeg ikke har spurt om, og som dere har lyst å få frem?

ii) -Har dere andre kommentarer rundt flerspråklighet som jeg ikke har spurt om, og som dere har lyst å få frem? 